\title{
Development and Quality Evaluation of Supplementary Food (Panjiri) Incorporating Processed B. juncea Meal
}

\author{
D. Goswami ${ }^{1,2 *}$, S. Sharma ${ }^{1}$, S. K. Tyagi ${ }^{2}$, B. Singh ${ }^{1}$ and H. M. Mandge ${ }^{3}$ \\ ${ }^{1}$ Department of Food Science and Technology, Punjab Agricultural University, \\ Ludhiana, Punjab, India \\ ${ }^{2}$ Food Grains and Oilseeds Processing Division, ICAR-Central Institute of Post Harvest \\ Engineering and Technology, Ludhiana, Punjab, India \\ ${ }^{3}$ Department of Post Harvest Technology, Banda University of Agriculture and Technology, \\ Banda, Uttar Pradesh, India \\ *Corresponding author
}

\section{A B S T R A C T}

\begin{tabular}{|l|}
\hline K e y w o r d s \\
Mustard meal, \\
$\begin{array}{l}\text { Supplementary } \\
\text { food, Panjiri, } \\
\text { Glucosinolates, } \\
\text { Color value }\end{array}$ \\
\hline Article Info \\
\hline $\begin{array}{l}\text { Accepted: } \\
\text { 12 November } 2020 \\
\text { Available Online: } \\
\text { 10 December } 2020\end{array}$ \\
\hline
\end{tabular}

The present study was aimed towards investigating the food application of processed mustard meal (PMM), which was obtained through a microwave-assisted processing for reduction of selected anti-nutrients, in a supplementary food (panjiri). During formulation of panjiri, the whole wheat flour was progressively replaced (0-20\%) with PMM and the panjiri samples were then evaluated for color, nutritional and sensory acceptability. Panjiri sample with whole wheat flour only was considered as control. Incorporation of PMM decreased the $\mathrm{L}^{*}, \mathrm{a}^{*}$ and $\mathrm{b}^{*}$ value of panjiri from $70.58,7.43$ and 25.32 to 59.74 , 5.36 and 17.63 , respectively. The total color difference $(\Delta \mathrm{E})$ was in the range of 4.13 to 13.46 indicating obvious color changes. The hue and chroma also decreased from 73.65 and 26.39 to 73.09 and 18.43, respectively with increasing PMM level. The sensory evaluation revealed that PMM based panjiri with 5\% replacement only was statistically similar to control in overall acceptability. However, the product was acceptable up to $10 \%$ incorporation level (OAA score 7.55) also. Nutritional analysis of most accepted PMM (10\%) based panjiri sample indicated $1.44 \%$ moisture, $14.64 \%$ crude fat, $1.20 \%$ total minerals, $9.23 \%$ crude protein and $73.48 \%$ total carbohydrates. The glucosinolates content was $2.20 \mu \mathrm{moles} / \mathrm{g}$ defatted sample.

\section{Introduction}

Mustard (Brassica juncea) meal is the byproduct produced after extraction of seed oil by physical or chemical processes or a combination thereof. About 60 per cent of residue is left as cake after oil extraction from the seed which is rich source of excellent nutritional quality protein (28-36 per cent) (Das et al., 2009). This potential alternative source of food protein generally finds its applications in animal and poultry feed only. Presence of certain anti-nutritional components such as glucosinolates (Tripathi 
and Mishra, 2007), phytates (Rutkowski and Kozlowska, 1979) and polyphenolics such as tannins (Sosulki, 1979) limit its food uses. However, the mustard meal can be diversified to food uses after microwave-assisted processing that is aimed towards reduction of certain anti-nutritional components (Goswami et al., 2020).

Panjiri is a traditional food product prepared from locally available flours of cereal grains such as wheat, rice or maize and legumes, sugar, ghee, and various dry fruits using household technologies like blending and roasting (Salve et al., 2011). The type and quantity of the ingredients may vary from place to place. It is usually consumed as a supplementary food for improvement of nutritional status by pregnant and lactating women (Sonkar and Singh, 2010; Satter Miah et al., 2016) because pregnancy and lactation are the most nourishment demanding stages of women's life. During these stages, the nutritional status of women is not only important for their health but is closely linked to the well being of the child also. The cereals although are good source of energy (350 calories per $100 \mathrm{~g}$ ), but are relatively poor source of protein. Hence, various studies have been aimed towards enhancing nutritional value of panjiri by incorporating other ingredients also (Gurwara et al., 2016; Kajale et al., 2014). The prevailing malnutrition among mothers and children of low socioeconomic groups has led Food and Agricultural Organization (FAO) to suggest development of supplementary foods based on locally available food crops also (Baskaran et al., 2001). In recent years, food utilization of by-products of food crops has also been emphasized and studied by many.

Hence, the present study was aimed towards investigating the effect of incorporation of $B$. juncea meal, obtained after microwaveassisted processing for reduction of selected anti-nutritional components, on nutritional and sensory acceptability of panjiri, a supplementary food.

\section{Materials and Methods}

\section{Preparation of PMM and panjiri}

Indian mustard seeds (cv PBR 91) were procured from Department of Plant Breeding and Genetics, PAU, Ludhiana (India). After cleaning and conditioning (10 per cent moisture) the oil expelling was done using Mini oil mill (Komet, CA59G, Germany). The cake left was repeatedly extracted with $n$ hexane to obtain defatted mustard meal $(\approx 1 \%$ fat) which was further subjected to microwave-assisted processing according to Goswami et al., (2020) to obtain processed mustard meal (PMM) which contained 9.53 $\mu$ moles glucosinolates/g defatted meal.

Panjiri samples were prepared after progressive replacement of whole wheat flour (0-20\%) with PMM in the formulation. Panjiri containing whole wheat flour only was taken as control. The formulation used for preparation of panjiri is given in Table 1. Whole wheat flour (atta) or the blend was roasted in ghee till proper browning (8-10 min) and then cooled to room temperature. The powdered sugar was then added and mixed properly. The panjiri samples were then packed in polypropylene bags for further analyses to assess the effect of incorporation of $B$. juncea meal.

\section{Color attributes}

The panjiri samples were evaluated for their color characteristics by using the HunterLab miniScan XE Plus colorimeter (Model 45/0L, HAL, USA). The samples were placed in petri dishes and data were recorded $(n=8)$ for $\mathrm{L}^{*}$ value (lightness, range $0-100$ ), a* value (redness/greenness) and $b^{*}$ value 
(yellowness/blueness). The $\mathrm{L}^{*}, \mathrm{a}^{*}$ and $\mathrm{b}^{*}$ values were further used to compute the total color difference $\left(\Delta \mathrm{E}^{*}\right)$, hue $\left(\mathrm{h}^{\mathrm{o}}\right)$ and chroma (C) as follows:

$\Delta \mathrm{E}^{*}=\left[\left(\Delta \mathrm{L}^{*}\right)^{2}+\left(\Delta \mathrm{a}^{*}\right)^{2}+\left(\Delta \mathrm{b}^{*}\right)^{2}\right]^{1 / 2}$

$\mathrm{h}^{\mathrm{o}}=\tan ^{-1}\left(\mathrm{~b}^{*} / \mathrm{a}^{*}\right)$

$\mathrm{C}=\left[\mathrm{a}^{*^{2}}+\mathrm{b}^{* 2}\right]^{1 / 2}$

\section{Sensory acceptability}

The sensory acceptability of panjiri samples was evaluated in terms of appearance, texture, flavour, taste and overall acceptability. The samples coded in random 3 digit numbers were evaluated by sensory panel comprising of 10 semi trained persons aged between 25 and 50. The panel rinsed their mouth with water in between the evaluation of different samples. The panellists were asked to score the sensory attributes on a Nine point Hedonic scale (1-dislike extremely to 9-like extremely).

\section{Determination of chemical constituents}

The proximate composition of control and 10\% PMM based panjiri sample (OAA score 7.55) was determined with the standard AACC (2000) methods. The glucosinolates content was determined according to the method of Kumar et al., (2004) with little modification as described by Goswami et al., (2020). Briefly, sample (0.2 g) along with 0.3 $\mathrm{ml}$ of $60 \%$ methanol was heated in a water bath $\left(80^{\circ} \mathrm{C}, 5 \mathrm{~min}\right)$ till complete evaporation of alcohol. After addition of distilled water (4 $\mathrm{ml}$ ), the content was subjected to heating again and centrifugation (4000 rpm, $20 \mathrm{~min}$ ). After mixing of $40 \mu \mathrm{l}$ of supernatant and $4 \mathrm{ml}$ of $0.2 \mathrm{mM}$ sodium tetrachloropalladate solution, the absorbance was recorded $1 \mathrm{~h}$ later at $405 \mathrm{~nm}$. The glucosinolates content was expressed as $\mu$ moles/g defatted sample against the standard of sinigrin. Minimum three replicates were assayed.

\section{Statistical analysis}

The analysis was performed at least in triplicate and results were expressed as means along with standard deviation. The significant difference between the samples $(\mathrm{P}<0.05)$ was determined with the help of analysis of variance (ANOVA) test using SPSS, Version 20 statistical software. In case of significant differences Tukey's Multiple Comparison Test was applied to determine mean values which differ significantly $(\mathrm{P}<0.05)$ from others.

\section{Results and Discussion}

\section{Color attributes of panjiri}

The color attributes of the panjiri samples in terms of $\mathrm{L}^{*}, \mathrm{a}^{*}$ and $\mathrm{b}^{*}$ value, total color difference, Chroma and Hue are shown in Table 2. The $\mathrm{L}^{*}, \mathrm{a}^{*}$ and $\mathrm{b}^{*}$ value of PMM was 47.11, 4.71 and 15.66, respectively. The processed mustard meal incorporation caused darkening of the product as evident by the decrease in $\mathrm{L}^{*}$ value of control (70.58) to 59.74 at 20 per cent PMM incorporation level and which may be attributed to the $\mathrm{L}^{*}$ value of the PMM itself. Similar effect of processed mustard meal incorporation on $\mathrm{L}^{*}$ value of cookies has been reported (Goswami et al., 2020).

The mustard meal, during the processing treatment, may have undergone some chemical changes such as Maillard browning leading to darkening of the meal which affected the lightness of the products also. There was observed decrease in redness with increasing level of PMM and is indicated by the decreased $a^{*}$ value from control (7.43) to 20 per cent PMM sample (5.36). There was greater yellowness in control panjiri sample (b* value 25.32 ) than the sample with maximum PMM level in the present investigation $\left(b^{*}\right.$ value 17.63$)$. 
Table.1 Panjiri formulation

\begin{tabular}{|l|c|}
\hline Ingredient & Quantity (g/100g) \\
\hline Wheat flour $($ Atta) / blend & 65 \\
\hline Powdered sugar & 22 \\
\hline Ghee & 13 \\
\hline
\end{tabular}

Table.2 Effect of PMM on color attributes of Panjiri

\begin{tabular}{|c|c|c|c|c|c|c|}
\hline \multirow{2}{*}{$\begin{array}{c}\text { PMM } \\
(\%)\end{array}$} & \multicolumn{6}{|c|}{ Color attributes of Panjiri } \\
\hline & $\mathbf{L}^{*}$ & $\mathbf{a}^{*}$ & $\mathbf{b}^{*}$ & $\Delta \mathbf{E}$ & Chroma & Hue $\left({ }^{0}\right)$ \\
\hline $\mathbf{0}$ & $70.58 \pm 0.92^{d}$ & $7.43 \pm 0.21^{\mathrm{c}}$ & $25.32 \pm 0.89^{e}$ & 0 & $26.39 \pm 0.88^{\mathrm{e}}$ & $73.65 \pm 0.50^{b}$ \\
\hline 5 & $68.79 \pm 0.80^{c}$ & $6.32 \pm 0.16^{b}$ & $21.84 \pm 0.44^{\mathrm{d}}$ & $4.13 \pm 0.47^{\mathrm{a}}$ & $22.74 \pm 0.42^{d}$ & $73.86 \pm 0.51^{b}$ \\
\hline 10 & $67.45 \pm 0.68^{b}$ & $6.28 \pm 0.23^{b}$ & $19.43 \pm 0.23^{\mathrm{c}}$ & $6.79 \pm 0.39^{b}$ & $20.43 \pm 0.24^{c}$ & $72.08 \pm 0.63^{\mathrm{a}}$ \\
\hline 15 & $59.92 \pm 0.37^{\mathrm{a}}$ & $5.45 \pm 0.34^{\mathrm{a}}$ & $18.76 \pm 0.26^{\mathrm{b}}$ & $12.68 \pm 0.34^{c}$ & $19.54 \pm 0.28^{b}$ & $73.80 \pm 0.96^{b}$ \\
\hline 20 & $59.74 \pm 0.60^{a}$ & $5.36 \pm 0.39^{\mathrm{a}}$ & $17.63 \pm 0.34^{\mathrm{a}}$ & $13.46 \pm 0.60^{d}$ & $18.43 \pm 0.37^{\mathrm{a}}$ & $73.09 \pm 1.12^{b}$ \\
\hline
\end{tabular}

PMM- Processed mustard meal

Data represent mean values \pm standard deviation $(n=8)$ for each sample. Mean values followed by different lowercase superscript letters within a column are significantly different $(\mathrm{P}<0.05$ using Tukey’s test)

Table.3 Effect of PMM on sensory acceptability of Panjiri

\begin{tabular}{|c|c|c|c|c|c|}
\hline \multirow{2}{*}{ PMM (\%) } & \multicolumn{5}{|c|}{ Sensory properties of Panjiri } \\
\cline { 2 - 6 } & Appearance & Texture & Aroma & Taste & OAA* $^{\mathrm{d}}$ \\
\hline $\mathbf{0}$ & $8.10 \pm 0.57^{\mathrm{b}}$ & $8.30 \pm 0.71^{\mathrm{c}}$ & $8.10 \pm 0.74^{\mathrm{b}}$ & $8.15 \pm 0.71^{\mathrm{d}}$ & $8.30 \pm 0.54^{\mathrm{c}}$ \\
\hline $\mathbf{5}$ & $8.15 \pm 0.41^{\mathrm{b}}$ & $7.70 \pm 0.54^{\mathrm{c}}$ & $7.95 \pm 0.80^{\mathrm{b}}$ & $8.00 \pm 0.53^{\mathrm{d}}$ & $8.05 \pm 0.44^{\mathrm{bc}}$ \\
\hline $\mathbf{1 0}$ & $7.80 \pm 0.59^{\mathrm{b}}$ & $7.45 \pm 0.69^{\mathrm{bc}}$ & $7.30 \pm 0.63^{\mathrm{a}}$ & $7.20 \pm 0.67^{\mathrm{c}}$ & $7.55 \pm 0.50^{\mathrm{b}}$ \\
\hline $\mathbf{1 5}$ & $6.75 \pm 0.98^{\mathrm{a}}$ & $6.65 \pm 1.06^{\mathrm{ab}}$ & $6.85 \pm 0.67^{\mathrm{a}}$ & $6.25 \pm 0.72^{\mathrm{b}}$ & $6.75 \pm 0.54^{\mathrm{a}}$ \\
\hline $\mathbf{2 0}$ & $6.35 \pm 1.20^{\mathrm{a}}$ & $6.30 \pm 1.09^{\mathrm{a}}$ & $6.70 \pm 0.54^{\mathrm{a}}$ & $5.30 \pm 0.82^{\mathrm{a}}$ & $6.20 \pm 0.54^{\mathrm{a}}$ \\
\hline
\end{tabular}

(PMM- Processed mustard meal; OAA- Overall acceptability)

Data represent mean values \pm standard deviation $(n=10)$ for each sample. Mean values followed by different lowercase superscript letters within a column are significantly different $(\mathrm{P}<0.05$ using Tukey's test)

Table.4 Nutritional composition of Panjiri

\begin{tabular}{|l|c|c|}
\hline Components & Control Panjiri & $\begin{array}{c}\text { 10 per cent PMM* } \\
\text { Panjiri }\end{array}$ \\
\hline Moisture (\%) & 0.28 & 1.45 \\
\hline Moisture (\%) & 0.28 & 1.44 \\
\hline Protein (\%) & 7.66 & 9.23 \\
\hline Crude fat $(\boldsymbol{\%})$ & 14.56 & 14.64 \\
\hline Ash $(\boldsymbol{\%})$ & 1.04 & 1.20 \\
\hline Carbohydrates $(\boldsymbol{\%})$ & 76.46 & 73.48 \\
\hline Glucosinolates $(\boldsymbol{\mu m o l e s} / \mathbf{g}$ defatted sample) & 0.00 & 2.20 \\
\hline
\end{tabular}


Progressive replacement of whole wheat flour with PMM even at 5 per cent level caused significant color difference as indicated by $\Delta \mathrm{E}$ value of 4.13. Further replacement linearly caused greater difference at each level of $\mathrm{PMM}$ incorporation with maximum $\triangle \mathrm{E}$ value of 13.46 at 20 per cent PMM level. The Hue and Chroma values also decreased with increasing level of PMM in the formulation.

\section{Sensory acceptability}

Sensory acceptability of the prepared panjiri samples was also determined using 9 Point Hedonic Scale for parameters such as appearance, texturel, aroma, taste and overall acceptability (Table 3). Results of appearance and overall acceptability showed that there was no significant difference $(p>0.05)$ between panjiri made by incorporating PMM. The addition of PMM decreased the mean score of appearance from 8.10 to 6.35. Panjiri prepared by incorporating 5 per cent PMM was ranked the most acceptable with an overall acceptability of 8.05 , whereas panjiri prepared by incorporating 20 per cent PMM ranked minimum with score of 6.20. The values for the score of taste of the panjiri samples ranged from 8.15 to 5.30. The presence of phenolic compounds in PMM that impart bitterness may be held responsible for the decreasing score for taste with increasing level of PMM.

\section{Nutritional analysis}

The control panjiri and panjiri prepared with maximum accepted PMM level (10\%) was analyzed for proximate composition and glucosinolates content. The observations are presented in Table 4. The panjiri samples exhibited protein content in the range of 7.66 to 9.23 and the higher value was for 10 per cent PMM based panjiri. Goswami et al., (2020) also reported increase in protein content of cookies upon incorporation of processed mustard meal. The ash content was 1.04 per cent in control and 1.20 per cent in the 10 per cent PMM panjiri. The glucosinolates were present in 10 per cent PMM panjiri (2.20 $\mu$ moles/g defatted sample) but the level was too low.

The health benefiting effects of glucosinolates have been established in literature as anticarcinogenic etc. but only when present in small quantity.

In conclusion the present study was carried out to diversify the use of B. juncea meal, a by-product of oil milling industry, in supplementary foods due to its greater protein content. Mustard meal application in food is generally limited by the presence of certain anti-nutritional components. This study established that $B$. juncea meal which is generally moved towards feed applications, could be used as an acceptable ingredient of panjiri after microwave-assisted processing that was aimed towards reduction of certain anti-nutritional components.

The incorporation of PMM affected the color attributes of panjiri and made it to appear darker. There was significant increase in total color difference with increasing level of PMM. The product made with maximum $10 \%$ PMM was found to be good in terms of sensory acceptability as well as nutritional indices. PMM incorporation increased the protein and ash content of the panjiri. From this study it may be concluded that utilization of B. juncea meal, an oil milling by-product, can be diversified to food uses after reduction of anti-nutritional components and enhancement of palatability through microwave-assisted processing. The processed $B$. juncea meal can thus be effectively utilized as an ingredient of supplementary foods propagating the 
important aspects like by-product utilization and low cost health foods using locally available crops.

\section{References}

AACC. 2000. Approved Methods of American Association of Cereal Chemists. 10th ed. The Association St. Paul, MN.

Baskaran, V., Mahadevamma, Malleshi, N. G., Jayaprakashan, S. G. and Lokesh, B. R. 2001. Biological evaluation for protein quality of supplementary foods based on popped cereals and legumes suitable for feeding rural mothers and children in India, Plant Foods for Human Nutrition. 56 (1): 37-49.

Das, R., Bhattacherjee, C., and Ghosh, S. 2009. Preparation of mustard (Brassica juncea L.) Protein isolate and recovery of phenolic compounds by ultrafiltration. Industrial and Engineering Chemistry Research. 48: 4939-4947.

Goswami, D., Sharma, S., Singh, B., and Tyagi, S. K. 2020. Effect of microwave-assisted processing of mustard meal on physicochemical and sensory properties of cookies. International Journal of Current Microbiology and Applied Sciences. 9(9): 2439-2446.

Gurwara, N. and Agarwal, S. 2016. Impact of soya multigrain panjiri supplementation on hemoglobin level among women in Raipur. International Journal of Home Science. 2(1): 22-24.

Kajale, N., Khadilkar, A., Chiponkar, S. and Unni, J. 2014. Effect of traditional food supplements on nutritional status of lactating mothers and growth of their infants. doi:10.1016/j.nut 2014.04.005.
Kumar, S., Yadav, S. K., Chauhan, J. S., Singh, A. K., Khan, N. A., and Kumar, P. R. 2004. Total glucosinolate estimation by complex formation between glucosinolates and tetrachloropalladate (II) using ELISA reader. Journal of Food Science Technology. 41: 63-65.

Rutkowski, A., and Kozlowska, H. 1979. Chemical constituents and protein food processing of rapeseed. Journal of American Oil Chemist Society 56:475477.

Salve, R.V., Mehrajfatema, Z.M., Kadam, M.L. and More, S.G. 2011. Formulation, nutritional evaluation and storage study of supplementary food (panjiri). Journal of Food Processing and Technology. 2:131. doi:10.4172/2157-7110.1000131.

Satter Miah, M. A., Abedin, N., Jabin, S. A., Islam, M. F., Begum, U. H. and Paul, D. K. 2016. A highly nutritive supplementary food: Improving the nutritional status of pregnant and lactating mothers. Agro Food Industry Hi Tech. 27(1): 40-45.

Sonkar, S. and Singh, V. 2010. To assess the nutritional composition of traditional supplementary foods consumed by lactating mothers in Kanpur city. Food Science Research Journal. 1(2): 202-204.

Sosulski, F. W. 1979. Organoleptic and nutritional effects of phenolic compounds on oilseed protein products: A review. Journal of American Oil Chemist Society. 56: 711-715.

Tripathi, M. K., and Mishra, A. S. 2007. Glucosinolates in animal nutrition: a review. Animal Feed Science and Technology. 132:1-27.

\section{How to cite this article:}

Goswami, D., S. Sharma, S. K. Tyagi, B. Singh and Mandge, H. M. 2020. Development and Quality Evaluation of Supplementary Food (Panjiri) Incorporating Processed B. juncea Meal. Int.J.Curr.Microbiol.App.Sci. 9(12): 1622-1627. doi: https://doi.org/10.20546/ijcmas.2020.912.192 